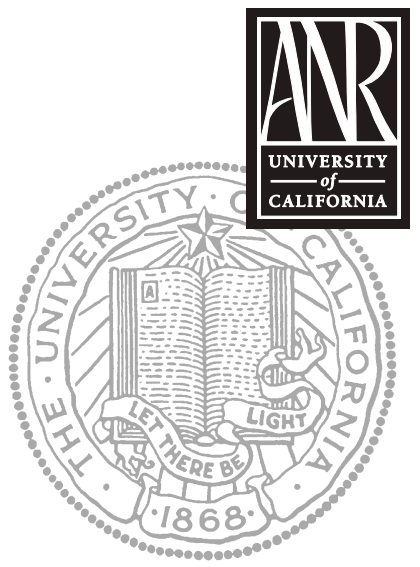

UNIVERSITY OF CALIFORNIA

Division of Agriculture and Natural Resources http://anrcatalog.ucdavis.edu

\title{
Producing Quality Almonds: Food Safety Starts on the Farm
}

BRUCE LAMPINEN, Department of Pomology, University of California, Davis, and JOSEPH CONNELL, University of California Cooperative Extension Farm Advisor, Butte County, in cooperation with the Almond Board of California

Minimizing the incidence of foodborne illnesses resulting from crop contamination is a concern for all almond growers. Bacteria that cause foodborne illnesses, such as Salmonella spp. and E. coli O157:H7, can be found in animal and human feces. The potential for contamination of almonds with these organisms increases during harvest, when the nuts are dropped to the ground. This publication highlights procedures that can reduce the potential for on-farm contamination of almonds.

\section{IRRIGATION AND WATER QUALITY CONSIDERATIONS}

- Identify your source of water for irrigation. Recognize that water may need to be tested and treated for pathogens prior to use.

- Make sure that water used for foliar applications is tested and treated for pathogens.

- Look carefully at your water delivery system for potential sources of pathogens. Shared irrigation pipelines could be a source of contaminated water.

- Diligently watch for potential water contamination sources from adjacent land (e.g., nearby landfills, septic tanks, leach fields, dairy operations, etc.).

- Recycled water (e.g., tertiary treated water) has been used in California for agricultural and landscape irrigation for many years without incident. However, if you use recycled water, obtain, review, and maintain copies of monthly reports available from the treatment facility. In particular, look for data on E. coli concentration, since this serves as an indicator of fecal contamination. Minimize the chance of recycled water coming into contact with nuts. For example, use drip irrigation and maintain the system properly to minimize puddling due to leaks or breaks.

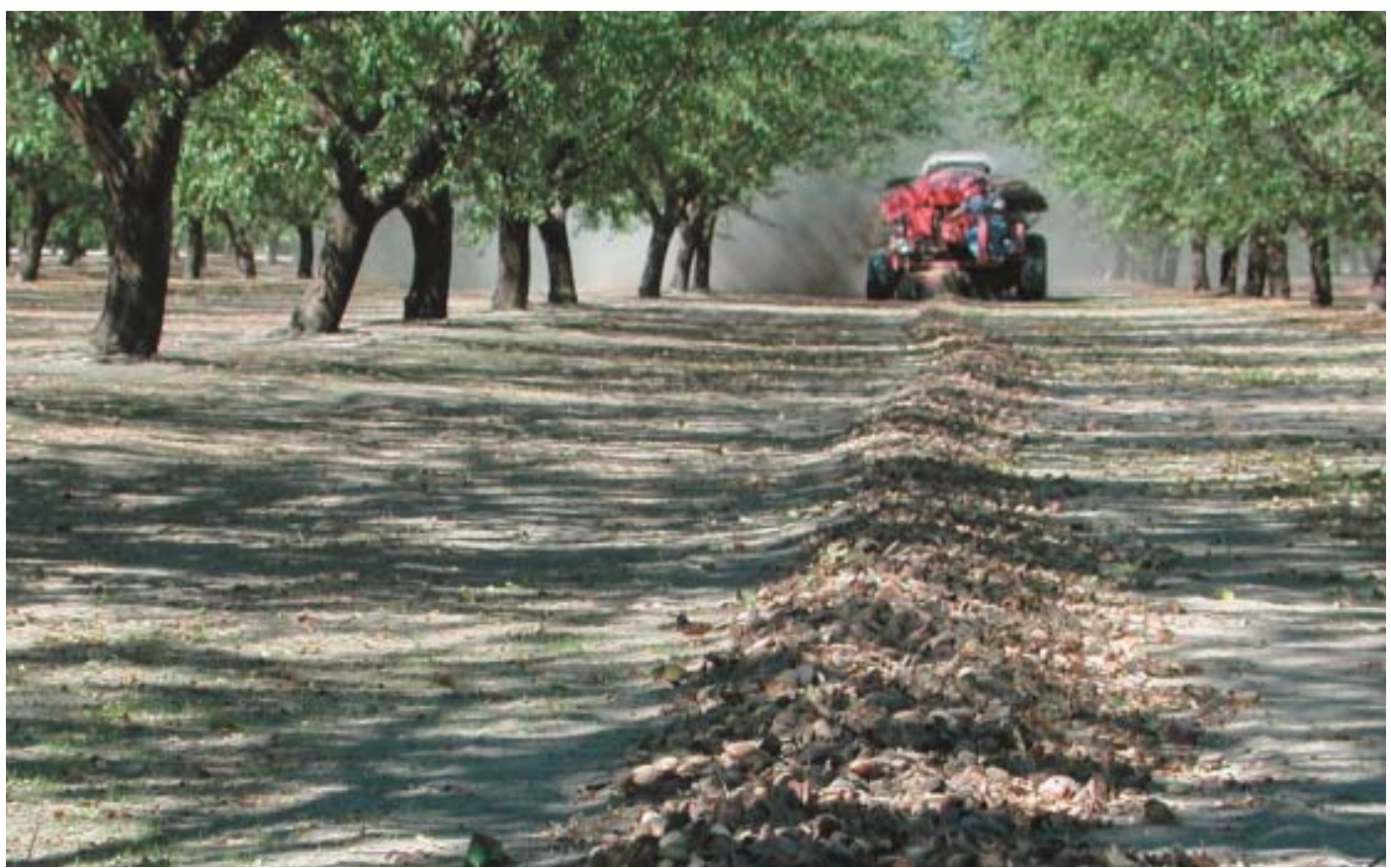




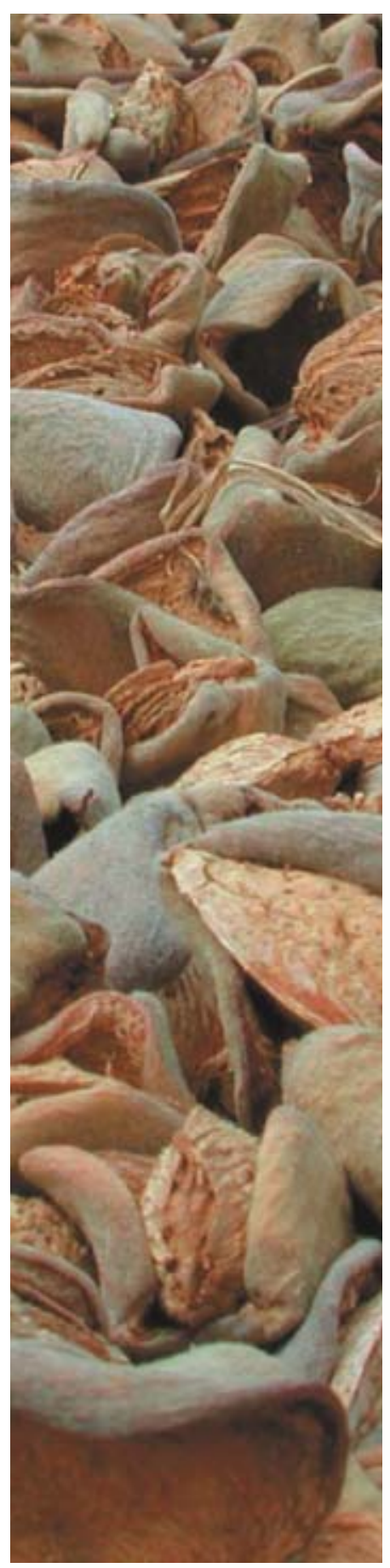

- If water sources are contaminated, employ mitigation measures such as filtration or chlorination of the water source.

- Be sure crop water needs are being adequately met without overirrigating by scheduling your irrigation using data based on plant water needs, soil moisture, or crop evapotranspiration.

\section{NUTRIENT APPLICATIONS}

The improper use of manure as a fertilizer is a potential contributory risk factor for foodborne illness. The highest risk is for crops in which the edible portion of the crop touches the ground. For almonds, this may occur at harvest. If you use manure, do so with food safety in mind. To minimize potential hazards:

- Do not apply biosolids or sewage sludge at any time.

- Do not apply raw or inadequately composted poultry or dairy manure or lagoon wastewater to the orchard floor during the growing season.

- If manure is used, use composted manure products that have undergone pathogen reduction, if possible. Ask the compost producer for:

- The percentage and physical makeup of composted material.

- Documentation showing that:

i. The compost temperature reached $131^{\circ} \mathrm{F}\left(55^{\circ} \mathrm{C}\right)$ for 15 days or longer.

ii. Compost windrows were turned a minimum of 5 times during the composting process.

iii. Microbial test results showing E.coli $<1,000 \mathrm{MPN} /$ gram and Samonella $<3$ MPN/4 grams (MPN = most probable number).

- If raw manure is used, apply as early after harvest as possible and disc thoroughly into the top layer of soil.

\section{VERTEBRATE PEST MANAGEMENT}

Minimize the possibility of contamination by bird, squirrel, or coyote fecal material by maintaining an active vertebrate pest management program in your orchard. As much as possible, exclude domestic and wild animals from orchards. Clean the orchard floor of any undesirable residue before starting harvest. Exclude all animals, especially rodents and birds, from all hulling facilities.

\section{HARVEST}

- Routinely maintain all harvesting and hulling equipment to ensure cleanliness. Wash with high pressure and sanitize all equipment prior to harvest.

- Avoid wet soil surfaces when the nuts are shaken or windrowed at harvest to prevent creating an environment conducive to bacterial growth.

- Keep the moisture content of nuts in windrows as low as possible.

- Properly adjust harvesters to minimize the amount of soil that is picked up during the harvest operation.

- Avoid stockpiling high-moisture almonds.

\section{WORKER SAFETY AND SANITARY OPERATING PROCEDURES}

- Maintain clean and sanitary restroom facilities for workers in close proximitywithin $1 / 4$ mile ( $400 \mathrm{~m}$ ) or 5 minutes' walk-to the work site.

- Review written procedures with workers regarding the use of toilet facilities, hand washing, and personal hygiene. 


\section{INDUSTRY REPUTATION}

The California almond industry has an excellent reputation for producing quality almonds. That reputation depends on growers doing their part to protect the quality of the food product. California markets depend on our product quality, reliability, and safety. Make sure you do what is necessary to protect our reputation so that we can always be proud of the quality and value our industry provides to the consumer.

\section{FOR FURTHER INFORMATION}

For more information on good agricultural practices regarding food safety, see the University of California Good Agricultural Practices Web Site at http://ucgaps.ucdavis.edu.

You'll find more information on almond production in the following ANR Communication Services products:

Almond Leaf Scorch, Publication 8106, 2003, available for free downloading at http://anrcatalog.ucdavis.edu/pdf/8106.pdf.

Almond Production Manual, Publication 3364, 1996.

Almond: UC IPM Pest Management Guidelines, Publication 3431, 2002, available for free downloading at http://www.ipm.ucdavis.edu/PDF/PMG/pmgalmond.pdf

Fungal Diseases of Almond Blossoms, Leaves, and Fruit, Publication 21588, 1999. Integrated Pest Management for Almonds, 2nd ed., Publication 3308, 2002. Training and Pruning Almond Trees / La guía y poda de los almendros, Video V88-BR, 1988.

For other products, visit the ANR Communication Services online catalog at http://anrcatalog.ucdavis.edu. You can also place orders by mail, phone, or FAX, or request a printed catalog of publications, slide sets, CD-ROMs, and videos from

University of California

Agriculture and Natural Resources

Communication Services

6701 San Pablo Avenue, 2nd Floor

Oakland, California 94608-1239

Telephone: (800) 994-8849 or (510) 642-2431; FAX: (510) 643-5470

E-mail inquiries: danrcs@ucdavis.edu

An electronic version of this publication is available on the ANR Communication Services Web site at http://anrcatalog.ucdavis.edu.

\section{Publication 8126}

(C) 2004 by the Regents of the University of California, Division of Agriculture and Natural Resources. All rights reserved.

The University of California prohibits discrimination against or harassment of any person employed by or seeking employment with the University on the basis of race, color, national origin, religion, sex, physical or mental disability, medical condition (cancer-related or genetic characteristics), ancestry, marital status, age, sexual orientation, citizenship, or status as a covered veteran (special disabled veteran, Vietnam-era veteran or any other veteran who served on active duty during a war or in a campaign or expedition for which a campaign badge has been authorized). University Policy is intended to be consistent with the provisions of applicable State and Federal laws.

Inquiries regarding the University's nondiscrimination policies may be directed to the Affirmative Action/Staff Personnel Services Director, University of California, Agriculture and Natural Resources, 300 Lakeside Drive, 6th Floor, Oakland, CA $94612-3550$ (510) 987-0096. For a free catalog of other publications, call (800) 994-8849. For help downloading this publication, call (530) 754-5112. 